\title{
BAT AND TERRESTRIAL MAMMAL INVENTORIES IN THE GREATER YELLOWSTONE NETWORK
}

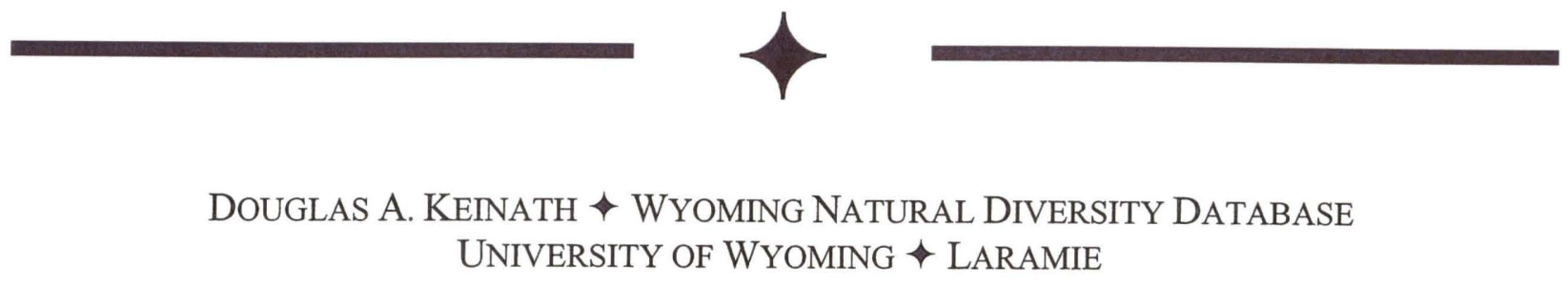

\section{$\downarrow \quad$ BACKGROUND AND INTRODUCTION}

The National Park Service (NPS) is undertaking a nationwide effort to inventory and monitor the biological resources within its management areas. Recognizing the need for a cross-boundary, ecosystem approach to natural resource management, the system of national parks has been grouped into Cooperative Ecosystem Units to facilitate inventory, monitoring, and subsequent management decisions in ecologically meaningful areas. The Greater Yellowstone Network (GYN) includes Yellowstone and Grand Teton National Parks (YNP and GTNP) and Bighorn Canyon National Recreation Area (BICA). A combined effort of biologists from these parks and regional wildlife experts resulted in the recent release of a study plan for the GYN inventory and monitoring efforts (NPS, 2000). This document identified significant gaps in information on the species richness, abundance, and distribution of bat species within all GYN parks and terrestrial mammals in BICA. They have therefore proposed that the NPS conduct a comprehensive inventory of bats throughout GYN and terrestrial mammals in BICA to establish a benchmark for future monitoring efforts and management actions. The specific goals of these inventory efforts, as stated in the GYN Study Plan (NPS, 2000), are as follows:

1. To document, through existing, verifiable data and targeted field investigations, the occurrence of at least 90 percent of the species of vertebrates and vascular plants currently expected to occur in Bighorn Canyon National Recreation Area, Grand Teton National Park, and Yellowstone National Park.

2. To describe the distribution and relative abundance of species of special concern, such as threatened and endangered species, non-native species, and other species of special management interest occurring within park boundaries.

3. To provide the baseline information needed to develop a general monitoring strategy and design that can be implemented by parks once inventories have been completed, tailored to specific park threats and resource issues.

4. To make information easily available to park managers, resource managers, scientists, and the public.

The studies discussed in this document are designed to generate a comprehensive inventory of bats in all three major GYN parks and of terrestrial mammals in BICA. Our main objective, as suggested above, is to document 90 percent of the species in these taxa that actually occur in these parks. Attainment of this objective is largely a result of the survey effort expended on these projects and is therefore directly related to the amount of time and money spent. There are many species in each inventory that will be easy to document (e.g., little brown bats). As species become more rare they will become harder to document and therefore more expensive (e.g., spotted bats). Therefore, (as a 
hypothetical example) documenting the first 70 percent of species may be straight forward, but the remaining 20 percent will be fare more difficult and time consuming. There is also a fine line defining when a species is rare versus so unlikely to occur in the area that it is not worth surveying (e.g., lynx in BICA).

\section{$\uparrow \quad$ METHODS}

\section{Methods: Bats}

We first identified and compiled all geographically referenced electronic data on features that might be useful in identifying important areas of bat use within and near the parks. We used this data to construct habitat suitability models identifying critical bat habitat for GTNP and YNP (priority areas were already identified for BICA and therefore no model was developed for the recreation area; Keinath 2001). These models incorporated wetland distribution, vegetative landcover, bedrock geology, elevation, and topographic relieve (slope and aspect), as outlined in Figure 1. Models were generated as raster coverages in a Geographic Information System (GIS) with 100 meter resolution. Six coverages were generated, one for each of the main components noted above. Each 100 meter cell in the park units was scored for each of these coverages and then a final habitat score was calculated for each cell by additively combining the six components (Figure 1).

\section{Figures and Tables}

Figure 1. Diagram of habitat suitability algorithy.

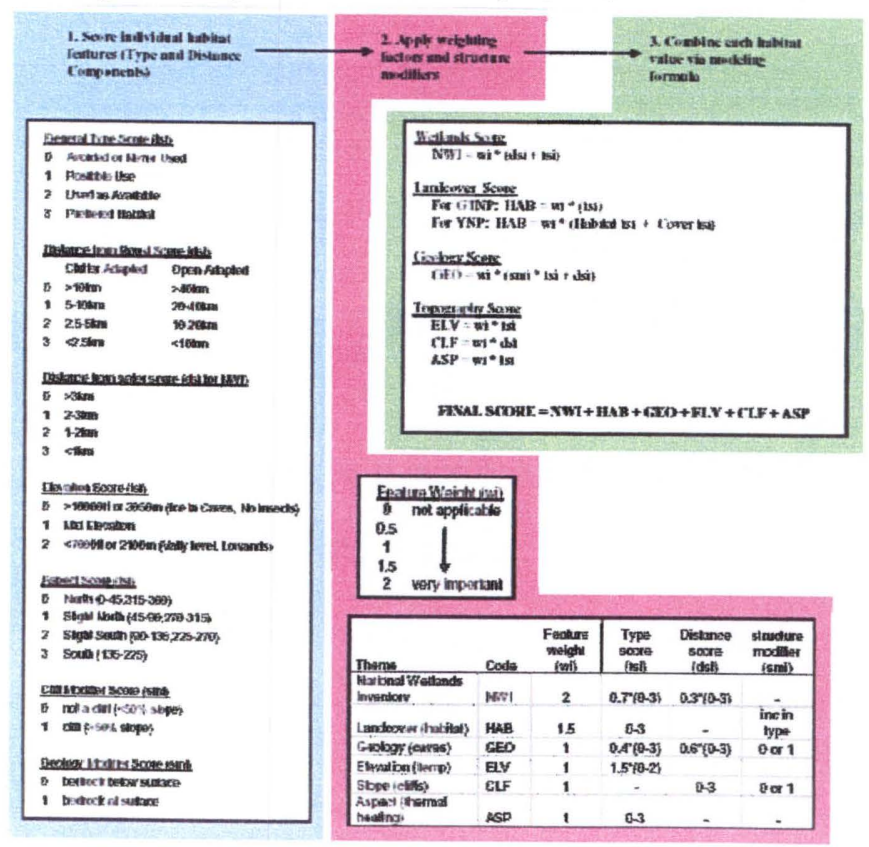

For instance, one of the 6 coverages was based on wetlands as classified by the National Wetlands Inventory (NWI). Each wetland type was given a "type score" of $0-3$ based on its suitability for use by bats as foraging and drinking habitat, where a score of 0 meant it was never used and a score of 3 meant it was preferred. A given cell was assigned a type score based on the wetland that it contained. Since proximity of a cell to other wetland areas also increases suitability, the same cell was also given a distance score, where low, unsuitable values (e.g. 0) represented long distances to other wetlands, and high, suitable scores (e.g., 3) represented proximity to other wetlands. The type and distance score for each cell was then weighted and combined into a single NWI coverage whose total range of scores was still $0-3$ (e.g., NWI score $=0.7 *$ type score $+0.3 *$ distance score). A similar process was followed for each of the other main components, resulting in five additional values for the given cell (i.e., $\mathrm{HAB}, \mathrm{GEO}, \mathrm{ELV}, \mathrm{CLF}$, and ASP), each having a score of $0-3$. The six values of each cell were added, weighting the most important components (wetlands and landcover) slightly more than the rest. This resulted in a final coverage in which each cell had a cumulative value of $0-22.5$, where higher valued cells were relatively more suitable for finding bats via mist netting and acoustic monitoring activities than lower valued cells.

This information was used in concert with input from park biologists to identify specific inventory sites. Sites were prioritized based on several factors including: 1 . their likelihood of being used by bats, 2 . the relative diversity of species likely to be present, 3. accessibility issues, and 4. their contribution to achieving a geographically inclusive sample from each park. Our goal was to make the most of our limited time in the parks, so we wanted to insure that sufficiently diverse habitat was sampled to capture all suspected species of bats. The ultimate goal of this phase was to generate an inventory site list to be surveyed repeatedly over the following two summers using the field methods noted below.

Depending on the nature of each site and the bat species expected, we used a variety of survey methods including, actively and passively operated acoustic bat detectors, mist nets, and harp traps. Bat detectors were used to determine the relative level of bat activity at each site and to preliminarily identify species based on characteristic vocalizations. We then employed mist nets and harp traps at potential roosting, foraging, and transit areas to capture, identify, and photograph the various bat species. 


\begin{tabular}{|c|c|c|c|c|}
\hline Species & $\begin{array}{l}\text { Expected } \\
\text { Presence * }\end{array}$ & Literature Source & Inventory Notes & $\begin{array}{l}\text { Surveyed in } \\
2003\end{array}$ \\
\hline $\begin{array}{l}\text { Black-tailed prairie dog (Cynomys } \\
\text { ludovicianus) }\end{array}$ & $\mathrm{P}$ & Anderson et al. 1984 & Visual survey for towns. & Yes \\
\hline $\begin{array}{l}\text { Thirteen-lined ground squirrel } \\
\text { (Spermophilus tridecemlineatus) }\end{array}$ & $\mathrm{P}$ & Anderson et al. 1984 & $\begin{array}{l}\text { Visual survey for burrows and } \\
\text { small mammal traps. }\end{array}$ & Partial \\
\hline $\begin{array}{l}\text { White-tailed prairie dog (Cynomys } \\
\text { leucurus) }\end{array}$ & $\mathrm{P}$ & Anderson et al. 1984 & Visual survey for towns. & Yes \\
\hline Swift fox (Vulpes velox) & $\mathrm{U}(\mathrm{A})$ & Anderson et al. 1984 & $\begin{array}{l}\text { Labor-intensive. Cameras, traps, } \\
\text { night spotting. }\end{array}$ & Partial \\
\hline $\begin{array}{l}\text { Northern flying squirrel (Glaucomys } \\
\text { sabrinus) }\end{array}$ & $\mathrm{HU}$ & Anderson et al. 1984 & Difficult to survey. Nest boxes. & Partial \\
\hline $\begin{array}{l}\text { Northern Pocket Gopher (Thomonys } \\
\text { talpoides) }\end{array}$ & $\mathrm{P}$ & ? (no source given) & Gopher traps. & No \\
\hline $\begin{array}{lll}\text { Southern } & \text { red-backed } & \text { vole } \\
\text { (Clethrionomys gapperi) } & \end{array}$ & $\mathrm{U}$ & Anderson et al. 1984 & Small mammal traps. & Yes \\
\hline Water vole (Microtus richardsonii) & $\mathrm{U}$ & Anderson et al. 1984 & Small mammal traps. & Yes \\
\hline $\begin{array}{l}\text { White-footed mouse (Peromyscus } \\
\text { leucopus) }\end{array}$ & $\mathbf{P}$ & Clark and Stromburg 1987 & Small mammal traps. & Yes \\
\hline American Marten (Martes americanna) & $\mathrm{U}(\mathrm{A})$ & Anderson et al. 1984 & $\begin{array}{l}\text { Labor-intensive. Cameras, track } \\
\text { plates, snow tracking. }\end{array}$ & No \\
\hline Ermine (Mustella ermina) & $\mathrm{U}$ & Anderson et al. 1984 & $\begin{array}{l}\text { Difficult to survey. Small mammal } \\
\text { traps and cameras. }\end{array}$ & Partial \\
\hline River otter (Lutra Canadensis) & $\mathrm{U}$ & Anderson et al. 1984 & Riparian track surveys. & Yes \\
\hline $\begin{array}{l}\text { Western spotted skunk (Spilogale } \\
\text { gracilis) }\end{array}$ & $\mathrm{P}$ & Clark and Strp,birg 1997 & Visual surveys. & Partial \\
\hline Moose (Alces alces) & $\mathrm{HU}(\mathrm{A})$ & ? (no source given) & Visual surveys and snow tracking. & No \\
\hline Fox squirrel (Sciurus niger) & $\mathrm{P}$ & Anderson et al. 1984 & Visual surveys. & Yes \\
\hline $\begin{array}{l}\text { Yellow-bellied marmot (Marmota } \\
\text { flaviventris) }\end{array}$ & $P$ & Anderson et al. 1984 & Visual surveys. & Partial \\
\hline $\begin{array}{l}\text { Yellow-pine } \\
\text { amoenus) }\end{array}$ chipmunk $\quad$ (Tamias & $\mathrm{U}$ & Patterson 1984 & Small mammal traps. & Yes \\
\hline Dusky shrew (Sorx monticolus) & $\mathrm{P}$ & Clark and Stromburg 1987 & Small mammal traps. & Partial \\
\hline Dwarf shrew (Sorex nanus) & $\mathrm{P}$ & Anderson et al. 1984 & Small mammal traps. & Partial \\
\hline House mouse (Mus musculus) & $\mathbf{P}$ & Anderson et al. 1984 & Small mammal traps. & Yes \\
\hline $\begin{array}{ll}\text { Meadow vole } & \text { (Microtus } \\
\text { pennsylvanicus) }\end{array}$ & $\mathrm{P}$ & Anderson et al. 1984 & Small mammal traps. & Yes \\
\hline Northern water shrew (Sorex palustris) & $\mathrm{P}$ & Anderson et al. 1984 & Small mammal traps. & Partial \\
\hline Sagebrush vole (Lemmiscus curtatus) & $\mathrm{P}$ & Clark and Stromburg 1987 & Small mammal traps. & Partial \\
\hline Lynx (Lynx canadensis) & HU (A) & Anderson et al. 1984 & $\begin{array}{l}\text { Labor-intensive. Cameras and snow } \\
\text { tracking. }\end{array}$ & No \\
\hline Vagrant shrew (Sorex vagrans) & $\mathrm{U}$ & Patterson 1985 & Small mammal traps. & Partial \\
\hline
\end{tabular}

All survey sites were located via GPS, bats were identified to species, their age and sex were determined, photographs were taken to document species occurrence, and the number of individuals captured was documented. No additional data was required by park service staff.

\section{Methods: BICA Mammals}

We reviewed an NP Species report from the GYN Inventory Coordinator that listed which species have been documented as occurring in BICA (Lane Cameron, pers. comm.). Of the 58 species recorded in the NP Species database, 37 were listed as present in the recreation area based on past studies (i.e., Anderson et al.). This leaves 21 species that might occur in BICA but which have not been formally documented. We feel that 4 additional species could occur in BICA that were not listed in NP Species, which yields a total of 25 species not documented by NPS, but possibly occurring in BICA based on range maps, habitat relationships, and existing observations (Table 1).

The most effective way to find any given species is to conduct intensive, targeted surveys for that species. However, given that the NPS does not have sufficient funds to conduct targeted surveys for each species listed in Table 1, our goal is to document as many species as possible using similar techniques, thus reducing the cost compared to independent surveys, while marginally decreasing detectability for any given species. Fortunately, many species can be surveyed efficiently with similar methodologies (e.g., Table 1). At the request of the NPS, voucher specimens of small mammals were collected by 
euthanizing the first incidence of capture. All other species were documented by photos of the animals or relevant signs (e.g., tracks, scat, burrows) if applicable. Although we did not focus any directed survey effort on species not listed in Table 1, we documented all species that we found.

Small mammals were surveyed via extensive trapping efforts using grids of baited Sherman live traps and Victor snap traps positioned in a variety of habitats to maximize chances of capturing habitat specialists. Extensive driving and/or foot-based visual surveys were conducted for evidence of prairie dog and ground squirrel burrows. Surveys for swift fox and spotted skunks were surveyed via a combination of bait stations with remote cameras and track plates as well as targeted nocturnal spotlight surveys. River otter surveys were conducted by performing a single-pass streamside search along permanent waterways for evidence such as tracks and latrine sites. Lynx, ermine, moose and northern flying squirrels were not surveyed, because they are very unlikely to occur in BICA and are difficult or labor intensive to survey. Should NPS wish to survey for these animals, we can conduct surveys for each, but they will entail additions to the budget for specialized searches. Moreover, these species may require inordinate effort relative to their likelihood of occurring in BICA.

\section{$\uparrow \quad$ RESULTS AND DISCUSSION}

Figure 2. Final bat habitat suitability model for Yellowstone National Park. Areas deemed suitable for netting the greatest diversity of bat species within Yellowstone National Park arehighlighted in maroon (top $2 \%$ of modeled area) and red (top $8 \%$ of modeled area). Focal areas for survey, in orderof decreasing priority, were 1 . areas of high maroon and red concentrations, 2. areas of high green concentrationswith some red, 3. areas of high green concentration, 4. under-represented habitat features or geographic areas.

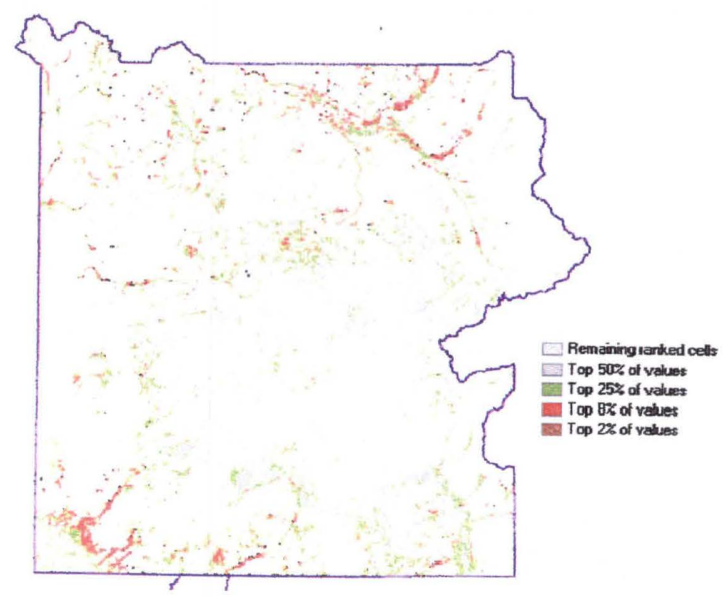

\section{Results and Discussion: Bats}

Habitat models (for GTNP and YNP) are displayed in Figures 2 and 3, in which the most suitable cells are shaded maroon and red and progressively less suitable cells are green, gray, and white. Focal areas for survey, in order of decreasing priority, are as follows:

1. areas of high maroon and red concentrations,

2. areas of high green concentrations with some red,

3. areas of high green concentration,

4. under-represented habitat features or geographic areas that don't appear in the model.

Figure 3: Final bat habitat suitability model for Grand Teton National Park. Areas deemed suitable for netting the greatest diversity of bat species within Yellowstone National Park arehighlighted in maroon (top $2 \%$ of modeled area) and red (top $8 \%$ of modeled area). Focal areas for survey, in orderof decreasing priority, were 1. areas of high maroon and red concentrations, 2. areas of high green concentrationswith some red, 3. areas of high green concentration, 4. under-represented habitat features or geographic areas.

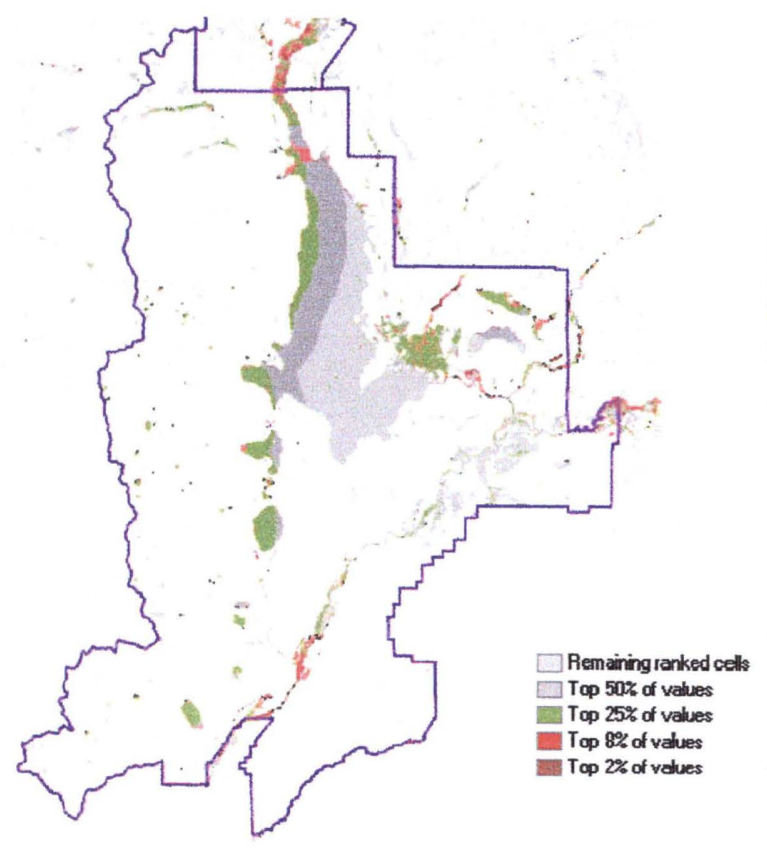

Based on this system, discussions with park biologists, and previous work done in BICA, the initial list of focal areas for which we conducted field visits was as follows:

BICA: Layout Creek (especially ponds by EwingSnell Ranch); BICA land near Yellowtail Wildlife Habitat Management Area (YWHMA); Hillsboro Ranch and beaver 
ponds; Lockhart Ranch and beaver ponds; Caves that on or near BICA (usually on BLM land, but whose bat population likely forages on the recreation area); Cliffs along the walls of Bighorn Canyon and Devils Canyon.

GTNP: Snake River South (including Blacktail Ponds and Moose-Wilson Ponds); Snake River North (including Glade Creek in JDRMP); Snake River Central (including Oxbow bend and Willow Flats); Foothills Lakes (including Moose Ponds and Lupine Meadows, String Lake, and some parts of western Jackson Lake and Leigh Lake); Pilgrim and Pacific Creeks; Northwestern GTNP (including Moose, Berry, and Owl Creeks).

YNP: Bechler area (including Bechler Canyon, Bechler Meadows and Falls River Basin); Lamar Valley area (including Lamar River, Slough Creek and Soda Butte Creek); Madison Junction area (including Madison River and Gibbon Basin); Grand Canyon area (including Yellowstone River and wetlands south of the canyon); Gardner's Hole area (including Gardner River, Africa Lakes and nearby wetlands); South Central Yellowstone (including Snake River and Lewis River south of Lewis Lake); Old Faithful area (including portions of the Firehole River).

Field technicians searched each of these broad focal areas to identify specific sites that were suitable for conducting mist net and acoustic monitoring activities. Approximately 170 sites were evaluated in this way, and mist netting was conducted on just over 30 of these (Figure 4).

Figure 4: Sample site distribution in the summer of 2003 throughout the Greater Yellowstone Network (parks are not to scale).

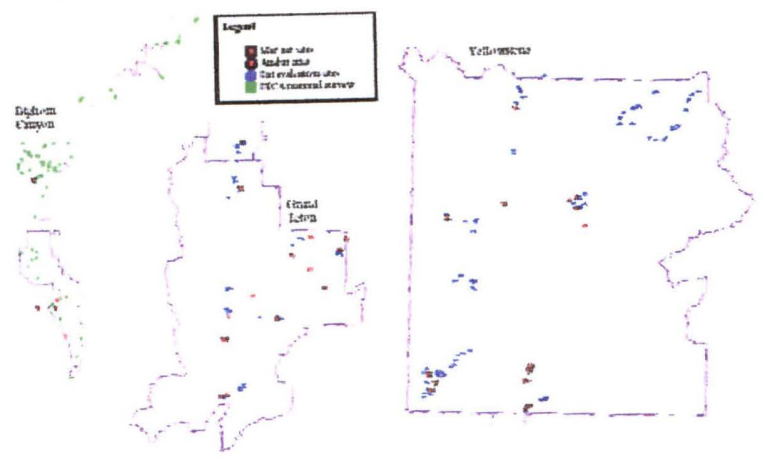

Over 36 nights of mist netting, we captured 527 bats of 12 species (Table 2). The most species rich area was BICA, which had nearly twice the amount of species in less than $9 \%$ and $1 \%$ of the land area of GTNP and YNP respectively. YNP had the greatest number of captures per unit effort, largely because of locally high concentrations of little brown bats (Myotis lucifugus). In general, GTNP and YNP were very similar in the apparent composition of their bat fauna and collectively they were much different that BICA.

The question of how close we are to documenting the complete suite of bats in each park is more difficult to answer. Expert opinion suggests that we are very close to the full compliment of bats in GTNP. However, BICA and YNP may yield more species with additional effort. A more quantitative estimate of progress can be roughly approximated by using rarefaction or species accumulation curves (e.g., Cam et al 2003, Krebs 1999). We developed species accumulation curves for each park unit (Figure 5). Although the effort to date is insufficient for formal analysis of richness predictions, we can gain an idea of our progress by studying the curves. The curve for GTNP (Figure 5b) clearly shows an asymptote at 6 species, which was reached early in our efforts. However, YNP and BICA (Figures 5a and 5c) seem to exhibit curves that have not clearly reached a maximum value. In the case of YNP there are two species that are likely to occur there but were not conclusively documented. We believe that both small-footed myotis (Myotis volans) and Townsend's big-eared bat (Corynorhinus townsendii) occur in YNP, but have not yet been captured in this study.

\section{Results and Discussion: BICA Mammals}

We conducted 30 small mammal trapping transects throughout BICA (Figure 4), 25 of which consisted of Sherman traps and Victor snap traps, and 5 of which consisted of pitfall traps with drift-fences. This resulted in a survey effort of 5,073 trap-days and 350 pitfall days. We captured a total of 603 small mammals of 12 species (Table 3). Of these, white footed mouse (Peromiscus leucopus) and house mouse (Mus musculus) were new additions to the mammal list of BICA (Table 1). These mice are both common in large portions of the country where they often out-compete other species. It is likely that they are extending their range into BICA and could competitively exclude other species from their preferred habitats. White-footed mice primarily occurred in riparian areas of BICA, while house mice 
were mainly found in riparian areas impacted by human activities (Table 1).

Figure 5. Bat species accumulation curves for each park uniot in the Greater Yellowstone Network.
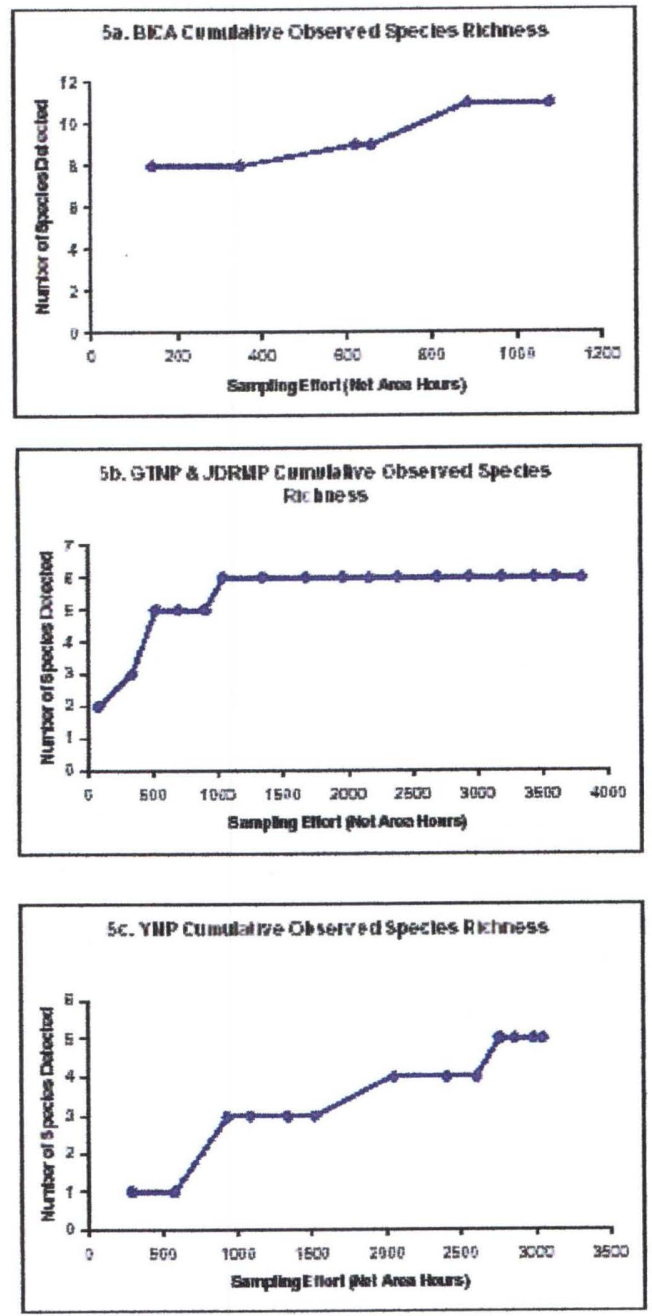

Species accumulation curves can be generated for small mammals at BICA, as they were for bats. Since no clear asymptote is apparent in such a graph (Figure 6), this exercise suggests that we have not currently spent sufficient effort to document all species present in the park. Thus, more small mammal trapping is necessary in the summer of 2004.

Additionally, we placed a limited number of remote cameras and baited track plates in areas suitable for detecting meso-carnivores and ground squirrels (e.g., skunks, swift fox, ermine, lynx, American marten). Photographs and tracks collected by these stations were primarily of deer mice, mule deer, antelope, and cottontail rabbits. No detections of heretofore undocumented mammals in BICA were made with cameras or track plates. We feel that more effort needs to be placed on surveys for these animals in the summer of 2004.

Figure 6. Small mammal species accumulation curve for Bighorn Canyon National Recreation Area.

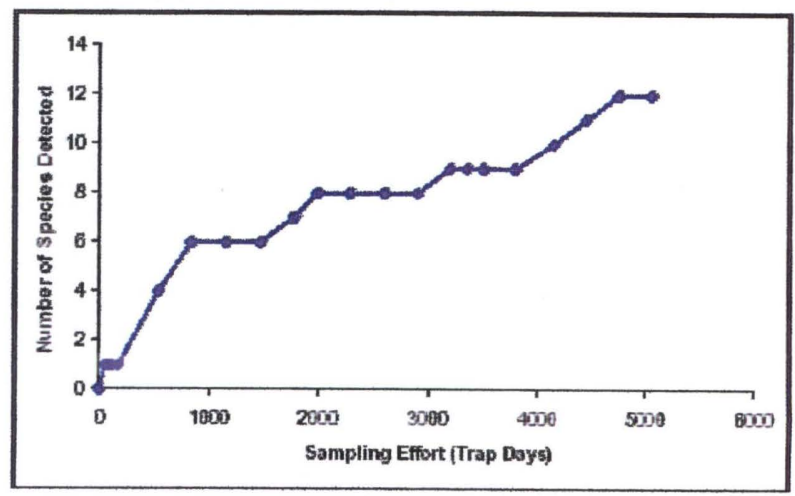

A single-pass in-stream survey for river otters was made along the main stem of the Bighorn River and Yellowtail Lake. No sign of otters (e.g., scat, latrine sites, tracks, slides, or actual animals) were found in BICA. We believe that these animals are not currently in residence in BICA. However, given recent distributional extensions for this species, we advise re-surveying the major waterways of BICA in the future.

Categorization and search of suitable habitat was conducted for prairie dogs. Very little suitable habitat exists in BICA and no prairie dogs were found during any searches. It is currently our belief that neither species of prairie dog occurs within BICA, although they are known to occur in more lowland areas of the Bighorn Basin. Selected surveys of additional areas for prairie dogs will be conducted in 2004 as time permits.

\section{Next Steps}

In general, field work in 2004 will focus on filling in gaps that remain despite previous work. We plan to work in BICA from about 1 May - 15 June, YNP from 1 July - 15 August, and GTNP from 15 August - 1 September.

We will focus bat survey effort in 2004 on YNP and BICA. We will re-sample the most productive sites from 2003 and add additional sites that were evaluated in 2003, but not mistnetted. These additional sites will be particularly important for YNP, as they will greatly increase the geographic distribution of our survey. We anticipate important additional sites for YNP in the Lamar Valley and its 
Table 2: Summary of bat identifications in the Greater Yellowstone Network for the summer of 2003 .

Table 2a. Bighorn Canyon National Recreation Area. Capture effort in BICA was approximately 22 hours (1,080 net area hours), resulting in an overall capture rate of about 8.6 X 10-2 captures per net area hour. ${ }^{*}$ Unlike the rest of the species on this list, the spotted bat was identified by audible calls and was not captured in a mist net.

\begin{tabular}{llr}
\hline \hline Species Name & Code & $\begin{array}{c}\text { Number } \\
\text { Captured }\end{array}$ \\
\hline Pallid bat (Antrozous pallidus) & 1 \\
Townsend's big-eared bat (Corynorhinus townsendii) & ANPA & 5 \\
Big brown bat (Eptesicus fuscus) & COTO & 34 \\
Spotted bat (Euderma maculatum) * & EPFU & 1 \\
Silver-haired bat (Lasionicteris noctivagans) & EUMA & 1 \\
California myotis (Myotis californicus) & LACI & 1 \\
Small-footed myotis (Myotis ciliolabrum) & MYCA & 12 \\
questionable Myotis califorinicus (specimen collected) & MYCI & 1 \\
Long-eared myotis (Myotis evotis) & MYCI/CA? & 8 \\
Little brown bat (Myotis lucifugus) & MYLU & 12 \\
unidentified myotis species & MYOTIS & 1 \\
Fringe-tailed bat (Myotis thysanodes) & MYTH & 1 \\
Long-legged myotis (Myotis volans) & MYVO & 3 \\
questionable Myotis yumanensis (specimen collected) & MYYU? & 93
\end{tabular}

Table 2b. Grand Teton National Park (including John D. Rockefeller Memorial Parkway) Capture effort in GTNP and JDRMP was approximately 67 hours (3,800 net area hours), resulting in an overall capture rate of about $4.2 \mathrm{X}$ 10-2 captures per net area hour.

\begin{tabular}{llr}
\hline \hline Species Name & Code & $\begin{array}{c}\text { Number } \\
\text { Captured }\end{array}$ \\
\hline Big brown bat (Eptesicus fuscus) & & 3 \\
Hoary bat (Laciurus cinereus) & EPFU & 14 \\
Silver-haired bat (Lasionicteris noctivagans) & LACI & 19 \\
Long-eared myotis (Myotis evotis) & LANO & 6 \\
Little brown bat (Myotis lucifugus) & MYEV & 113 \\
Long-legged myotis (Myotis volans) & MYLU & 6 \\
Total & MYVO & 161
\end{tabular}

Table2c. Yellowstone National Park. Capture effort in YNP was approximately 50 hours (3,060 net area hours), resulting in an overall capture rate of about 8.9 X 10-2 captures per net area hour.

\begin{tabular}{llc}
\hline Species Name & Code & $\begin{array}{c}\text { Number } \\
\text { Captured }\end{array}$ \\
\hline Big brown bat (Eptesicus fuscus) & & 3 \\
Hoary bat (Laciurus cinereus) & EPFU & 1 \\
Silver-haired bat (Lasionicteris noctivagans) & LACI & 4 \\
Long-eared myotis (Myotis evotis) & LANO & 1 \\
Little brown bat (Myotis lucifugus) & MYEV & 264 \\
Total & MYLU & 273
\end{tabular}


tributaries, the Gardner's Hole area, the Old Faithful area, and the Mammoth area. For additional work in BICA we plan to investigate roosting activity in caves just outside the recreation area (these bats likely forage in BICA) and conduct acoustic monitoring of the main reservoir. After field work is complete, we will analyze all data using formal statistical tools to estimate total species richness in each park unit. This will provide a quantitative estimate of what proportion of species we successfully documented.

We will continue small mammal trapping surveys in BICA for the summer of 2004. We will increase the effort placed on pitfall traps and snap traps, to better sample shrews. Also, we will increase sample effort for mesocarnivores by employing more remote cameras and track plates. Further, visual surveys for pocket gopher activity and prairie dogs will be implemented as time permits.

\section{$\uparrow \quad$ REFERENCES}

Anderson, S. H., W. A. Hubert, and D. Duvall. 1984. Vertebrate inventory for Bighorn Canyon National Recreation Area. Eighth Annual Report of the National Park Service Research Center, University of Wyoming, Laramie, Wyoming.
Cam, E., J. D. Nichols, J. R. Sauer, and J. E. Hines. 2003. On the estimation of species richness based on the accumulation of previously unrecorded species. Echography 25:102108.

Keinath, D. A. 2001. Bat Habitat Delineation and Survey Suggestions for Bighorn Canyon National Recreation Area. Report prepared for the North American Bat Conservation Partnership and Bighorn Canyon National Recreation Area by the Wyoming Natural Diversity Database, Laramie, Wyoming.

Krebs, C. J. 1999. Ecological methodology, 2nd Ed. Addison-Welsey Educational Publishers, Inc., Menlo Park, California. 
Table 3: Small mammal capture summary for Bighorn Canyon National Recreation Area.

3a. Captures by species for BICA transects in June - July 2003.

\begin{tabular}{lcc}
\hline Species Name & Total & Captures per \\
& Captures & 100Trap Days \\
\hline Ord's kangaroo rat (Dipodomys ordii) & 13 & 0.26 \\
Long-tailed vole (Microtus longicaudus) & 1 & 0.02 \\
Prairie vole (Microtus ochrogaster) & 29 & 0.57 \\
House mouse (Mus musculusI) & 39 & 0.77 \\
Bushy-tailed wood rat (Neotoma cinereal) & 13 & 0.26 \\
White-footed mouse (Peromyscus leucopus) & 59 & 1.16 \\
Deer mouse (Peromyscus maniculatus) & 424 & 8.36 \\
Western harvest mouse (Reithrodontomys megalotis) & 9 & 0.18 \\
Unidentified shrew (Sorex spp.) & 2 & 0.04 \\
Juvenile cottontail rabbit (Sylvalagus spp.) & 1 & 0.02 \\
Least chipmunk (Tamias minimus) & 11 & 0.22 \\
Western jumping mouse (Zapus princeps) & 1 & 0.02 \\
Total Captures & 603 & 11.89
\end{tabular}

\author{
3b. Species captured by major habitat \\ category Riparian (dominant vegetation is \\ cottonwood, \\ willow, tall grass, or flood plain herbaceous) \\ Prairie vole (Microtus ochrogaster) \\ House mouse (Mus musculus) \\ White-footed mouse (Peromyscus leucopus) \\ Deer mouse (Peromyscus maniculatus) \\ Western harvest mouse (Reithrodontomys megalotis) \\ Unidentified shrew (Sorex spp.) \\ Least chipmunk (Tamias minimus)
}

Human Riparian (riparian vegetation is dominant and the area is proximate to human structures such as houses, picnic areas, etc.)

Ord's kangaroo rat (Dipodomys ordii)

Prairie vole (Microtus ochrogaster)

House mouse (Mus musculus)

Bushy-tailed wood rat (Neotoma cinereal)

White-footed mouse (Peromyscus leucopus)

Deer mouse (Peromyscus maniculatus)

Western harvest mouse (Reithrodontomys megalotis)

Juniper (dominant overstory vegetation consists of juniper spp. sometimes mixed with other conifer) Deer mouse (Peromyscus maniculatus) Juvenile cottontail rabbit (Sylvalagus spp.)
Least chipmunk (Tamias minimus)

Sagebrush (dominant vegetative cover consists of Artemisia spp.)

Deer mouse (Peromyscus maniculatus)

Shrub-Grassland (landscape is a mixture of shrubs, including sagebrush, rabbit brush, and greasewood, and grasslands)

Long-tailed vole (Microtus longicaudus)

Prairie vole (Microtus ochrogaster)

White-footed mouse (Peromyscus leucopus)

Deer mouse (Peromyscus maniculatus)

Western harvest mouse (Reithrodontomys megalotis)

Unidentified shrew (Sorex spp.)

Least chipmunk (Tamias minimus)

Western jumping mouse (Zapus princeps)

Conifer (dominant overstory cover is lodgepole pine, sprucefir

mix, limber pine, or ponderosa pine)

Prairie vole (Microtus ochrogaster)

Bushy-tailed wood rat (Neotoma cinereaI)

Deer mouse (Peromyscus maniculatus)

Western harvest mouse (Reithrodontomys megalotis) 